\title{
Causal Factors of Low Achievement in EFL Development: Findings from a Chinese University
}

\author{
Fei Ma \\ School of Basic Science, Zhejiang Wanli University, Ningbo 315101, China
}

\begin{abstract}
A large number of university students have poor performance in English language learning in mainland China. It is important to learn the cause of this phenomenon in order to give the learners effective intervention. The current study clarifies two terminologies, i.e., underachievement and low achievement. The phenomenon of low achievement is investigated with the tools of interview, questionnaire survey and classroom observation. Among the many possible factors, four factors stand out as the critical causal factors: effort, interest, teachers and prior attainment. Six factors show a moderate association with their performance and exert limited influence. They are peers, attitude, learning strategy, confidence, curriculum and motivation. Some seemingly important factors, such as gender, family background and learning ability, actually have little association at all. The study also finds that a certain percentage of low achievers could be reversed if right scaffolding is given.
\end{abstract}

Index Terms - low achievement, causal factors, EFL, intervention

\section{INTRODUCTION}

The higher education in mainland China is hierarchical, with a categorization of tier-1, tier-2 and tier-3 universities. Tier-1 universities are the elite institutions under the funding and governance of central or local government. The universities entitled 'double first-class' fall under this category and are the leaders of this group. Tier-2 universities are ordinary institutions that are funded and governed by local government. Tier-3 universities are under the governance of local government, and usually do not, or partially receive government funding. They are not seen as competitive as their tier-1 and tier-2 counterparts. Therefore, the tier-3 universities usually have to recruit students with lower performance in terms of gaokao score. Comparatively, low achievement is a much more serious problem in tier-3 universities. Among the 1217 institutions offering undergraduate education in mainland China, approximately one third is tier-3 universities and about 24 percent of undergraduate entrants are enrolled here (MoE, 2014, 2015). However, the educational problems in tier-3 universities usually attract much less research interest, because the influential experts usually work at tier-1 universities and they know less and worry less about the teaching and learning in the territory of tier-3 ones. Many problems here concerning teaching and learning remain underexplored.

English language education is compulsory in China's curriculum system. It usually starts from Year Three in primary schools and ends at universities. In the level of higher education, the course is known as College English. As China plays increasingly important roles in the globalization of economy and internationalization of education, English as a lingua franca becomes especially important for university students, considering their future work and further education. The tier-3 universities share many commonalities in EFL education in terms of the entrants admitted, the educational resources, and their standing in the Chinese higher education system. The educational authorities take the pass rate of CET-4, a national English proficiency test, as an important index to assess education quality. As the quality assessment is more sensitive to tier-3 universities, they generally attach great importance to English education.

The university under research is a tier-3 university in eastern China. The course of College English is compulsory for all first-year students, totally with 14 credits. Around 4300 students take College English each semester. The students have to pass the course to get the credits; meanwhile, they are encouraged to pass CET-4. Pass of CET-4 is a precondition to obtain honours degree. Furthermore, CET-4 certificate could ensure better job opportunities. English learning, therefore, is very important for students.

The students are enrolled from 24 different provinces in China, covering a variety of regions from east to west, south to north, and rural to urban. Their English proficiency varies greatly. The majority of students have a reasonably good mastery of the four skills. However, every year in the class I teach, I always notice a group of students with very poor performance. Some of them have to repeat the course more than once, which costs tremendous extra time, and puts the students under great anxiety. I have communicated this with my colleagues a couple of times, and they report similar phenomenon. Without doubt, there exist a group of students who are struggling with their English learning. It is a big number when it is put under the context of the whole university. For example, according to the data from Centre for Foreign Languages Education, in the first semester of school year 2015-2016, 558 students failed the course of College English. This roughly indicates 12.4 percent of students have problem in EFL learning, which worries all the 
stakeholders. In order to help this group of students effectively, it is important to understand the causal factors of their low achievement.

\section{DEFINING LOW ACHIEVERS}

The concepts of 'underachievers' and 'low achievers' are often conflated and used interchangeably. In some occasions, they depict the same group of students, but most cases not. An underachiever academically performs more poorly than their potential learning ability. Identification of underachievers usually requires two variables, the student's actual achievement and their potential ability. The underachiever shows a strong discrepancy between actual achievement and potential ability (Dowdall \& Colangelo, 1982; McCall, 1994; Reis \& McCoach, 2000; Rimm, 1997; Whitmore, 1980). That is, the underachievers are those who have the potential to achieve better academic results. Thus, there is a need to distinguish two further concepts: high achieving underachievers (HAUs) and low achieving underachievers (LAUs), as Figure 1 indicates. For example, the students who achieve respectable results but with potential to be the top ones are HAUs. The students whose achievement is at the lowest level but with the potential to perform better are LAUs.

Figure 1 depicts the relationship between underachievers and low achievers (LAs). LAs refer to those who achieve very poor academic outcomes. Low achievement is measured by student's actual achievement, that is, low achievers have a very wide achievement gap with their peers. The way to measure could be examinations or tests accompanied by their teacher's subjective assessment. This measurement does not consider student's potential ability. The measuring criterion of low achievement is often self-determined and does not have universal standard.

In the broad sense, the connotation of low achievers is dichotomous. The construct can refer to those who have a discrepancy between actual achievement and potential ability, i.e. LAUs. The construct also includes the type of low achievers who have no discrepancy between actual achievement and potential ability, that is, they have little potential to obtain better academic outcomes. This group of students can be termed as the students with learning difficulties (SLDs). LAs are sometimes defined in the narrow sense. For example, they refer to those who have a below average IQ and struggle in the classroom to keep up with general academic requirements (VanAuker-Ergle, 2003). In the narrow sense, LAs exclusively refer to SLDs, namely those with little discrepancy between actual achievement and potential ability.

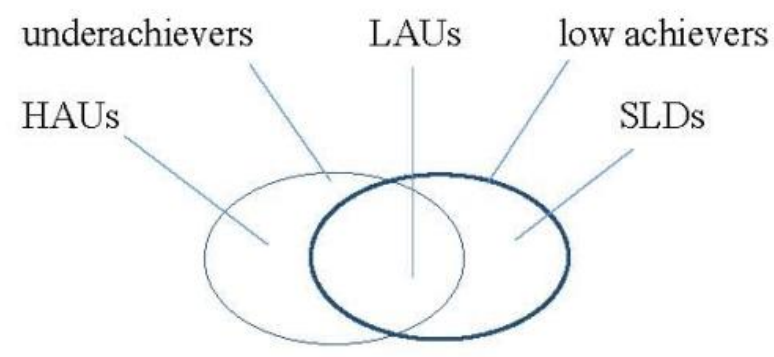

Figure 1 Interrelation between underachievers and low achievers

The current research defines LAs in the broad sense. The term refers to those who have low achievement in English learning, without considering their potential abilities. That is, it includes both LAUs and SLDs. I do not separate LAUs and SLDs because it is beyond the agenda of current research to test students' potential English learning ability, therefore it is almost impossible to distinguish the two groups. Secondly, there exists fierce competition to be admitted to universities in China. It is therefore assumed that there is only a very small number of SLDs among university students. Thirdly, in the Chinese language, the direct translation of this group of students is low achievers. Therefore, the current research prefers the terminology low achievers.

My identification of LAs is a comprehensive consideration of their gaokao score and their teacher's subjective assessment. The full mark of gaokao English exam is 150. If students score lower than 90, they are usually believed to perform poorly in English learning. Those with gaokao English scores lower than 90 are considered to be possible LAs, and their English teacher's assessment works as a supplementary criterion to evaluate their achievement. Furthermore, I understand that the learning status of students may change for better or worse in their learning process; therefore, their achievement is dynamic. The categorization of LAs is only meaningful at that certain period of time.

\section{METHODS}

The current research adopts a mixed design with the tools such as questionnaire survey, classroom observation, and semi-structured interview to collect data. The institution under research has 51 specialties, covering the disciplines of natural science, arts and humanities, and social science. Students from different disciplines are assumed to perform differently in English learning. The samples must represent the three different disciplines, that is, the samples should be able to display the general feature of the whole university. Therefore, I chose one class from each discipline, i.e., one class of journalism, one class of law and one class of environmental engineering. The three classes were selected 
because they were neither the best nor the worst in English achievement in their respective discipline, and their students and teachers were happy to participate in the research. This cohort of students was admitted in year 2016.

A review of literature indicates that 12 factors may have close association with English low achievement. The factors include prior attainment, interest, effort, motivation, confidence, learning strategy, peers' influence, curriculum, teacher's impact, IQ, gender difference and family background. My questionnaire design is based on the 12 factors. The major part of the questionnaire is Likert scales that are used to learn about the respondent's perceptions about each factor. Another item asks students to pick out four most critical factors contributing to EFL low achievement from the 12 -factor bank. The last item is an open question, where respondents can write down the causal factors they think important but not covered by the bank. The questionnaire survey was conducted among the three classes and the EFL teachers at the university. The returned valid questionnaires include 152 copies from students and 44 from teachers.

Seven LAs from the three classes were identified with the help of their English teachers, and they were voluntary to participate in the interview. They are Jack, John, James, Juliet, Hurley, Sayid and Charlie. The interview centres on their English learning experience, and what has caused their low achievement. In addition, I interviewed the three English teachers of the three classes, Ben, Kate and Sun. The interview concentrates on what the causal factors are and how the factors could be dealt with. The interview was conducted on a one-to-one and face-to-face basis, and each one lasted for around 30 minutes.

The classroom teaching and learning of each class was observed for two or three times. I adopted the approach of non-participant observation. Each time the observation lasted for one period of lesson (45 minutes). The students' selflearning activity was observed as well. In this university, each class is assigned a regular self-learning room. All students are required to attend the self-learning activity from 7:00 to 7:30 a.m. each day from Monday to Friday. Students are encouraged to learn English at that time. The self-learning activity of each class was observed twice.

These three sets of data are analysed independently first, and then merged by comparison, contrast and reconciliation. Hopefully the different source of data could illuminate each other and the findings could be triangulated.

\section{FINDINGS}

The current research finds that the influence of factors varies according to contexts. In one context, some factors may stand out as the critical factors; in another, the factors may retreat as insignificant in relation to the learning outcomes. As is shown in Table 1 and Table 2, some seemingly important factors actually play insignificant roles in term of current research interest. They are gender, family background and IQ. Gender is found to be a superficial factor, i.e., the real difference between male and female learners lies in their different effort and interest. The family exerts huge influence upon children when they are in primary and junior high schools, but exercises very limited influence in higher education. Fierce competition exists in China's primary and secondary education. If the students have IQ problem, they are not likely to have the chance to go to university. Therefore, the university students rarely have the IQ problem.

In the emergence of EFL low achievement, some factors exert influence, but the influence is not powerful enough to change the trajectory of learning. The influence is a quantity accumulation. In other words, they are not critical in giving rise to EFL low achievement. A comprehensive analysis of the three sets of data identifies six factors with moderate association, i.e., peers, attitude, learning strategy, confidence, curriculum and motivation. This study finds that

- Strong peers promote learning, and weak peers undermine it.

- Quite a number of students hold that English is dispensable in their life.

- Many learners do not have a clear understanding of learning strategy.

- The repeated setbacks in secondary school have exhausted the confidence of LAs.

- The current curriculum is too demanding for weak learners.

- The learners have strong instrumental motivation, but weak integrative motivation.

Effort, prior attainment, and interest are found to be the critical factors directly linking to EFL low achievement (Table 1 and Table 2). A big controversy exists about whether the teacher's role is critical. The survey results suggest the teacher's impact is insignificant, but the interviews indicate otherwise. 
TABLE 1

CAUSAL FACTORS INDICATED By QUESTIONNAIRE SURVEY

\begin{tabular}{|c|c|c|}
\hline & $\begin{array}{l}\text { Factors /frequency / percentage } \\
\text { (student's questionnaire, } N=152 \text { ) }\end{array}$ & $\begin{array}{l}\text { Factors /frequency / percentage } \\
\text { (teacher's questionnaire, } \mathrm{N}=44 \text { ) }\end{array}$ \\
\hline 1 & Lack of interest /118/77.6 & Poor prior attainment/40 /90.9 \\
\hline 2 & Poor prior attainment /113 /74.3 & Lack of interest /33/75.0 \\
\hline 3 & Lack of effort $/ 90 / 59.2$ & Lack of effort $/ 29 / 65.9$ \\
\hline 4 & Lack of motivation /84/55.3 & Lack of motivation /26/59.1 \\
\hline 5 & Lack of confidence $/ 73 / 48.0$ & Lack of confidence /21/47.7 \\
\hline 6 & Poor learning strategy /58/38.2 & Poor learning strategy /18 /40.9 \\
\hline 7 & Peers' adverse influence $/ 26 / 17.1$ & Peers' adverse influence /4 /9.1 \\
\hline 8 & Inappropriate curriculum /19/12.5 & Inappropriate curriculum $/ 2 / 4.5$ \\
\hline 9 & Teacher's adverse impact /18/11.8 & Teacher's adverse impact $/ 2 / 4.5$ \\
\hline 10 & Low $I Q / 6 / 3.90$ & Gender difference $/ 1 / 2.3$ \\
\hline 11 & Gender difference /3/1.97 & Low $I Q / 0 / 0$ \\
\hline 12 & Disadvantaged family background $/ 0 / 0$ & Disadvantaged family background $/ 0 / 0$ \\
\hline
\end{tabular}

TABLE 2

FACTORS IDENTIFIED BY INTERVIEWEES

\begin{tabular}{|l|l|l|}
\hline & $\begin{array}{l}\text { Factors /frequency } \\
\text { LAs, N=7) }\end{array}$ & $\begin{array}{l}\text { Factors /frequency } \\
\text { (teachers, N=3) }\end{array}$ \\
\hline 1 & Lack of effort /7 & Poor prior attainment /3 \\
\hline 2 & Poor prior attainment /6 & Lack of interest /3 \\
\hline 3 & Lack of interest /5 & Lack of effort/3 \\
\hline 4 & Teacher's adverse impact/4 & Teacher's adverse impact/2 \\
\hline 5 & Peer's adverse influence/4 & Inappropriate attitude /2 \\
\hline 6 & Inappropriate attitude /3 & Lack of confidence /2 \\
\hline 7 & Poor learning strategy /3 & Poor learning strategy /1 $/ 1$ \\
\hline 8 & Lack of confidence /1 & Peer's adverse influence / \\
\hline 9 & Bad memory /1 & \\
\hline 10 & Low IQ /0 & Low IQ /0 \\
\hline 11 & Gender difference /0 & Gender difference /0 \\
\hline 12 & Disadvantaged family background/0 & Disadvantaged family background/0 \\
\hline
\end{tabular}

\section{Teacher's impact}

This controversy of attribution is resolved by a deeper analysis of the data collection process and the data set per se. Some bias might exist when respondents answered the questionnaires. The item asks respondents to identify the key causal factors for EFL low achievement. It is human nature to avoid being blamed and being labelled as incompetent. Teacher respondents are reluctant to claim themselves as the cause of student's low achievement. The student survey was conducted in the class break. Chinese students usually do not want to have confrontations with their teachers by indicating their teacher's incompetence. They tend not to attribute low achievement to the teachers in public space.

The interview reveals that English teacher is one of the key causal factors. The interview took place in the private space and confidentiality was assured, so the interviewees were relieved to reveal the truth. For example, Kate was critical of some colleagues straightforwardly. She claimed that 'most teachers have given up this group of students ...' The university evaluates the teaching quality by calculating the CET-4 passing rate of each class. Transforming LAs usually demands much more efforts and it is difficult. The utilitarian way is to focus on the students who have more potential to pass the test. Kate also accused some colleagues of being irresponsible and indifferent. She revealed the case of one teacher. 'She does not check attendance and leave assignments, and is arbitrary at the teaching content. She manages to let her students pass the course, so she is popular among some students.' It is easy to speculate that this indulgence and ingratiation could reduce student's effort making.

In the same vein, four LAs asserted that teachers had strong association with their learning outcomes. They accused their teachers for various reasons. John never practiced listening in junior high school, but his teacher in senior high lectured everything in English. He could not understand the lesson, hence his interest was lost and he put his effort on other subjects. Jack complained that 'the English teaching in my secondary school was boring, so I did not want to follow'. Juliet blamed that 'my high school teacher was poor at class management; the class was often in chaos'. Juliet was very daring. She had two English teachers at the university, and she complained of one teacher by saying 'that teacher's lesson is very boring; many of us choose not to listen'. Hurley was unsatisfactory with his secondary school teachers, who always asked them to have rote memorization of vocabulary, therefore his interest was lost. The LAs did not complain of the teachers whose class I went for observation. When they talked of the teachers, they spoke well of them. The student interviewees were selected with the help of the teachers. They are on good terms with the teachers, and they were unwilling to speak ill of their teachers. However, we should not assume that there are no problems among these teachers.

The importance of teachers' role is further verified by classroom observation. The three classes show very different teaching and learning status. The class of journalism was most engaged. The students were very attentive, showing little distractive behaviours. The students of law were generally cooperative and with the teacher, although a small number of students were doing irrelevant things. The learning status of the engineering class is worrisome. Nearly half of students 
were not focused, displaying the behaviours such as playing with cell phones, napping, chatting, and absent-mindedness. The teacher is not the only factor contributing to the different learning status, however, the attitude of teachers plays important role. Being strict with students or not directly affects the class learning atmosphere. Students may play truant, come late, be less engaged, show more disruptive behaviours if the teacher is too loose with class management. Kate is strict with students and the wrongdoers will be asked to have a talk or punished, which pushes students to make more efforts. Her students have to refrain from distractive behaviours. The lesson preparation matters as well. The teacher who did not prepare the lesson carefully tended to spend more class time on less relevant things, and the lecture was usually boring.

In Kate's words, 'a responsible and caring teacher can make a big difference in turning LAs around'. Ben shares this opinion by emphasizing that encouragement from a teacher can help students build up confidence, thereby enhancing performance. The case of John fully supports this claim. John was bottom three in his class when he came to the university. In his words, English was like 'the language of mars and the foe of my last life' at that time. He could not understand the language and hated it very much. However, he was lucky to meet a good teacher Kate who gave him encouragement and support. His English proficiency was approaching the middle level and still had potential to improve after one semester's effort. Ben reported an anecdote of another student. The English proficiency of that student was not good then. Ben once said to the student that 'your voice sounds quite mellow and your English speaking must be very pleasant to hear'. This simple encouragement greatly helped the student to build up confidence and make efforts. The student got reasonably good results in the final exam. He even took part in English speaking contest and shared his learning experience with his classmates. That is, teachers can exert great influence upon student's English learning, especially in the aspect of affection.

The English teachers at this university generally graduate from tier-1 universities, and usually hold a master degree or above. All of them have a teaching experience of at least 15 years. I worry less about their teaching ability. The problem lies in the teaching attitude of some teachers. If they make more efforts in teaching and give more support to the LAs, more LAs could be transformed.

Effort

The efforts students make have significant and positive association with academic achievement throughout lower and higher education (Alexander, Entwisle, \& Dauber, 1993; Alexander, Entwisle, \& Horsey, 1997; Carbonaro, 2005; Coates, 2009; Connell \& et al., 1994; Diseth, Pallesen, Brunborg, \& Larsen, 2010; Fredricks, Blumenfeld, \& Paris, 2004; Ho \& Hau, 2008; Marks, 2000; Michaels \& Miethe, 1989; Pike, Kuh, McCormick, Ethington, \& Smart, 2011; Stewart, 2008). Some Chinese research shows that effort is one of the most important factors contributing to the English performance of Chinese university students (Cui, 2007; Ou, 2012). The current findings show great convergence with the previous research. Both students and teachers assume that lack of effort is one of the key factors resulting in EFL low achievement (Table 1 and Table 2).

In Ben's words,

'They failed the final exam ... they invested little effort in learning and their time is wasted'.

Kate has similar claim,

'The most decisive reason for low achievement lies in not enough individual effort'.

According to the three teachers, the LAs often skip class and fail to finish assignments. They do not have the inner willingness to learn. They may be present in class physically but not engaged mentally. They usually display the behaviours such as playing with cell phones, napping, chatting, or absent-mindedness. Some of them have been found copying assignments, even cheating in exams.

All the seven LAs admit that lack of effort is a major reason for their present learning outcome. The case of Hurley illustrates this point well, though extreme. It seems that he does not make any efforts in English learning and other subjects as well. Hurley is very frank.

'Our generation, after high school, won't give much concern to study... In high school, I might have to study for 18 hours each day; but now I may allocate 18 hours for life and three hours for study... In my first semester, I could play computer for 24 hours a day, and I forgot study. As time passes, it becomes a habit, that is, there is no study in my life."

'I want to live the university life I have dreamt of, comfortable and relaxing. Study only takes up a very small part of my life... Our generation has different understanding of university life with yours... I almost do not study now and my effort making is the least throughout my learning history.'

Sayid was not as extreme as Hurley, but he also admitted he did not make enough efforts.

'Last semester, I almost did not make any efforts because I was busy with some other work... This semester, I start to memorize vocabulary as CET-4 is approaching. I am a little worried. I am not very hard-working, but I am working for that goal.'

'My effort is far from enough. The students who really work hard have detailed plans. For example, they have a plan for the number of words to memorize every day and they are determined to finish the task. As far as I am concerned, I may memorize several words in the morning or some in the evening. I do not have a plan.' 
Their lack of effort is triangulated by the observation of self-learning activity. The observation demonstrates that their effort is far from enough, which is especially reflected in the law class and class of environmental engineering. A huge number of students were not studying during the half-hour self-learning time. They played with cell phones, listened to music, chatted and so on. They waited for the end of the session, and time was wasted.

Prior attainment

The current research defines prior attainment as the English proficiency the students possess before they start their higher education. Gaokao English score is a major indicator of their prior attainment. The surveys and interviews reveal that poor prior attainment is a major causal factor for present EFL low achievement (Table 1 and Table 2).

Sun gave detailed illustration about this. A few students in her class are from underdeveloped provinces such as Sichuan and Inner Mongolia. They did not receive any listening training in their high school, and were totally overwhelmed in the listening class. Another issue is that students are not taught phonetic symbols in their primary and secondary schools. They do not know how to pronounce new words. These problems have a link to educational policy.

In Kate's opinion, one thing the LAs have in common is that their English has been already lagged behind at their secondary school. They rarely experienced the sense of success. Ben echoed this by claiming that there were ten percent of students in his class whose English proficiency was around the level of junior high. It was almost impossible to have any communication with them in English, and they had no ability to finish their assignments. He once asked his students to be honest with their homework. They could just draw a straight line if they did not know the answer. It turned out that their assignment books were full of straight lines.

In fact, the LAs themselves also recognize their poor prior attainment, and believe it is the major difficulty for them to catch up. The interview of LAs reveals that some of them are poor in their overall English proficiency; others may have a big problem in some specific areas, such as listening, grammar or vocabulary. For example, Jack admitted that his overall English proficiency was among the worst in his class, and he could only understand half of the lecture even if he tried hard. His low achievement started from his junior high school, because he had no interest and was halfhearted in learning then. His gaokao English score is only 49 out of 150 . Charlie has some in common with Jack. In his words, 'I almost could not understand anything about English; Nobody could be worse than me'. He alleged that he had not been engaged in English learning since his junior high, because he was lazy and fun-loving. He almost did not memorize vocabulary. He recalled his gaokao score as around 65.

The LAs have different attribution of their poor attainment. The English proficiency of James was at the bottom of his class. His low achievement started from his high school, and he scored 87 in gaokao. He ascribed this to his bad memory. He tended to forget the vocabulary even if he memorized the words for two or three times. He felt exhausted. However, he could easily memorize the difficult Chinese poems. In his words, 'my brain is like a Chinese operating system; if an English software is squeezed in, it doesn't run well.'

John told a different story. He never received listening training in junior high school; however his English teacher in senior high lectured everything in English. He could not understand, so he lost interest and put effort on learning other subjects. His gaokao score is 85 . His English proficiency was bottom three in his class at the outset of his university education, but he was making rapid progress then.

Hurley admitted that his English was not good, which started from high school. There were too many words to memorize and he hated doing so. His gaokao score is 85. The experience of Sayid shared some similarity with Hurley. Sayid's low achievement began at high school and he hated memorization as well. Another reason is that he spent a lot of time reading novels in his high school, which distracted his English learning. His gaokao score is 70, and he claimed that his English proficiency was quite poor currently.

As can be seen, the LAs share the problem of poor prior attainment, which is a complex construct associative with many variables such as educational policy, teachers, interest, effort, attitude, and so on. However, no LAs attribute their low achievement to ability. The finding is in accordance with the previous research that prior attainment is the most important predictor for present academic achievement (Bloom, 1971, 1974, 1976; Dochy, 1992; Parkerson \& et al., 1984). This has implication that educational authorities should recognize the existence of low prior attainment and its influence upon academic achievement. It is better not to arbitrarily assert that 'the students won't be admitted to university if they do not have the corresponding attainment', and blame the teachers that 'there are no unteachable students, only incapable teachers'.

\section{Interest}

It is universally acknowledged that greater interest brings about students' focused attention, persistent effort, increased cognitive and affective functioning, hence higher achievement (Ainley, Hidi, \& Berndorff, 2002; Hofer, 2010; Renninger \& Hidi, 2011; Woolfolk, 2010). Likewise, the current research finds that lack of interest is a key factor resulting in the low achievement (Table 1 and Table 2).

Five LAs pointed out that lack of interest is one of the major reasons leading to their low achievement, and they lost it for various reasons. In John's case, English listening was not tested in zhongkao ${ }^{l}$; therefore his listening was never practiced in junior high. A big gap arose between him and his peers in senior high. He felt he had no ear for English.

\footnotetext{
${ }^{1}$ Zhongkao is the entrance examination for senior high schools. In Zhejiang province, 50 percent students have the chance to go to senior high schools. Others have to attend vocational schools.
} 
His interest was lost. In his words, 'It is like someone talking to you with the language of Mars; my interest was totally lost'. John lost interest because of the unfavourable external stimuli.

Jack's lack of interest was more intrinsic. He had little interest in English and was half-hearted in learning at primary school. As a result, he felt his English proficiency had lagged behind substantially since year six. Currently, he wanted to pass CET-4; however the gap was too wide for him to close in short time. In fact, every learner has their own story. James was once very good at English, but he lost his interest in senior high. He attributed this to his bad memory. He tended to forget the English words. He exclaimed that 'I feel exhausted and disheartened; English becomes a headache to $m e$ '.

Hurley was straightforward that he lost interest in English in grade two senior high. Before that, he liked English and its culture very much, e.g. English novels and music. In his words, 'English letters look prettier than Chinese characters.' At that time, he once thought of studying abroad and he was confident he was able to reach that English proficiency. Afterwards, his thought changed and he found staying in China was not bad. Another reason for his loss of interest lies in, 'there are too many words to memorize; I hate it', as he put it. As a result, his interest was lost. The cases of Hurley and James indicate that interest is dynamic. It may change over time. This has implications that stimulating interest and holding it are both important. Moreover, the dynamics of interest could bring about the change of other factors, effort for example.

The experience of Charlie shares some similarity with Hurley. In Charlie's words, 'I just don't like it; I don't like memorizing vocabulary.' He did not memorize enough words in junior and senior high schools; therefore he could not understand the reading, which made him more unwilling to learn. Currently, because of the stimulation of CET-4, he thought of trying to learn English. However, he was very pessimistic in that he was poor at almost every aspect, such as vocabulary, grammar, sentence structure and writing. 'My prior attainment is too weak', he confessed.

The LAs agree that lack of interest greatly affects their learning outcomes. It seems that their interest has already been lost in junior or senior high school, and it continues till now. The three teachers agree that lack of interest is one key causal factor for low achievement, whereas they have different interpretation of the reasons for their lack of interest. Kate put it simply, 'It is interest ... Many students consider learning English or not won't make a big difference for their life.' In Ben's opinion, these students were frustrated repeatedly in their junior and senior high schools. Their interest was exhausted then. However, Ben believes interest can be triggered once again. He turned around a low achieving student by giving encouragement, which helped the student develop interest and confidence.

According to Sun,

'They don't like it, not because they are not capable. They just don't like learning.'

'Their interest was not developed when they began to touch English. They were taught under passivity and compulsion. It would be hard for them to develop interest in English when they grew up'.

The LAs generally have lost interest in English learning for quite a long time. Re-triggering their interest is difficult, but it must be argued that it is possible. For example, John had the experience of interest loss in high school and its regain in the university. He has made great progress since then. It must be noted that the trigged interest could be lost easily if measures were not taken to hold it.

Finally, a happy finding is that a certain percentage of LAs are reversible. The seven LAs are confident of their learning potential. They attributed their current learning outcome to other factors rather than ability. A typical example is John, who has transformed to a mid-achiever after one semester's effort. This convertibility is corroborated by the following data. According to my statistics, there are 1621 students whose English gaokao score is lower than 90 in this cohort. 215 of them turned the tide and passed CET-4 after one year's learning. This roughly means 13 percent transformed from LAs to HAs. By exploring the causal factors, it is hoped that a larger percentage of LAs could be reversed if more effective intervention is given.

\section{DISCUSSION AND CONCLUSION}

EFL low achievement is the result of multiple factors. These factors are interactive and dynamic. They influence and are influenced by other factors, therefore form a relationship of reciprocal causation. The dynamism of the factors indicates that the learning outcome is dynamic. The performance of learners may change over time, for better or for worse. Among the factors, four play the critical role in the emergence of EFL low achievement, i.e., poor prior attainment, lack of effort, lack of interest, and teacher's adverse impact. They can be defined as the key causal factors. The causal factors intertwine to generate a collective force to exert influence upon EFL development. EFL low achievement emerges mainly under the influence of the four factors. In order to help the LAs, the four factors should be dealt with as a priority. These four factors can be further refined into two themes, i.e. affect-relevant and academicsrelevant, as Figure 2 depicts. The affect-relevant theme is mainly represented by effort and interest, with some links to prior attainment and teachers. The academics-relevant theme is chiefly reflected by prior attainment and teachers, with some associations with effort and interest. This is a refined model on how EFL low achievement is developed and how intervention should be designed. This model reveals that the intervention design should primarily consider how to address the LAs' affective and academic problems in terms of these four factors. Among the two, handling the affective problem appears to be especially important for it encourages LAs to take initiatives to learn. The teachers and the university could have different focus in terms of intervention. The teachers could mainly focus on dealing with the 
affective variables, that is, develop LAs' interest and motivate them to make efforts. The university could put priority on handling the academic variables by developing some supporting programs for LAs, and stimulating teachers to be actively engaged in teaching.

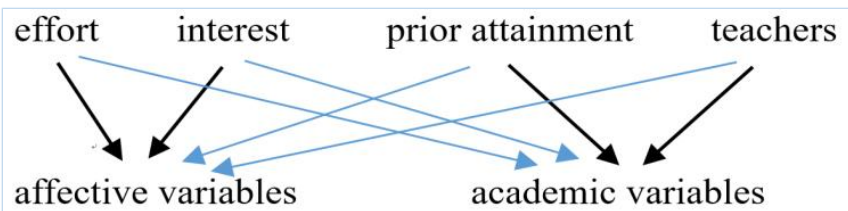

Figure 2 The refined model of EFL low achievement

The current research sees EFL development as a complex system composing of learners, teachers and learning environment, which are under the influence of multiple factors. EFL low achievement is the unfavourable emergence of the system, which is not easy to change without powerful perturbation. Owing to the interactivity and dynamism of the causal factors, it demands the concerted and persistent effort of the three parties to reverse the LAs.

\section{REFERENCES}

[1] Ainley, M., Hidi, S., \& Berndorff, D. (2002). Interest, Learning, and the Psychological Processes That Mediate Their Relationship. Journal of Educational Psychology, 94(3), 545-561.

[2] Alexander, K. L., Entwisle, D. R., \& Dauber, S. L. (1993). First- Grade Classroom Behavior: Its Short- and Long- Term Consequences for School Performance. Child Development, 64(3), 801-814. doi:10.2307/1131219.

[3] Alexander, K. L., Entwisle, D. R., \& Horsey, C. S. (1997). From First Grade Forward: Early Foundations of High School Dropout. Sociology of Education, 70(2), 87-107.

[4] Bloom, B. (1971). Mastery learning: theory and practice. New York: Holt, Rinehart and Winston.

[5] Bloom, B. (1974). Time and learning. American Psychologist, 29(9), 682-688. doi:10.1037/h0037632.

[6] Bloom, B. (1976). Human characteristics and school learning. New York: McGraw-Hill.

[7] Carbonaro, W. (2005). Tracking, Students' Effort, and Academic Achievement. Sociology of Education, 78(1), 27-49.

[8] Coates, H. (2009). Engaging Students for Success - 2008 Australasian Survey of Student Engagement. Retrieved from Victoria, Australia: http://research.acer.edu.au/cgi/viewcontent.cgi?article=1017\&context=higher_education_(accessed 10/5/2017).

[9] Connell, J. P., \& et al. (1994). Educational Risk and Resilience in African- American Youth: Context, Self, Action, and Outcomes in School. Child Development, 65(2), 493-506.

[10] Cui, Y. (2007). The Study of University Students' Self-attribution on Success and Failure in English Learning. (master), Zhengzhou University, Zhengzhou.

[11] Diseth, A., Pallesen, S., Brunborg, G., \& Larsen, S. (2010). Academic achievement among first semester undergraduate psychology students: the role of course experience, effort, motives and learning strategies. Higher Education, 59(3), 335-352. doi:10.1007/s10734-009-9251-8

[12] Dochy, F. (1992). Assessment of Prior Knowledge as a Determinant for Future Learning: The Use of Knowledge State Tests and Knowledge Profiles. Utrecht/London: Lemma B.V./Jessica Kingsley.

[13] Dowdall, C. B., \& Colangelo, N. (1982). Underachieving Gifted Students: Review and Implications. Gifted Child Quarterly, 26(4), 179-184.

[14] Fredricks, J. A., Blumenfeld, P. C., \& Paris, A. H. (2004). School Engagement: Potential of the Concept, State of the Evidence. Review of Educational Research, 74(1), 59-109.

[15] Ho, I. T., \& Hau, K.-T. (2008). Academic achievement in the Chinese context: The role of goals, strategies, and effort. International Journal of Psychology, 43(5), 892-897. doi:10.1080/00207590701836323.

[16] Hofer, M. (2010). Adolescents' Development of Individual Interests: A Product of Multiple Goal Regulation? Educational Psychologist, 45(3), 149-166. doi:10.1080/00461520.2010.493469.

[17] Marks, H. M. (2000). Student Engagement in Instructional Activity: Patterns in the Elementary, Middle, and High School Years. American Educational Research Journal, 37(1), 153-184.

[18] McCall, R. B. (1994). Academic Underachievers. Current Directions in Psychological Science (Wiley-Blackwell), 3(1), 15-19. doi:10.1111/1467-8721.ep10769838.

[19] Michaels, J. W., \& Miethe, T. (1989). Academic Effort and College Grades. Social Forces, 68(1), 309-319.

[20] MoE. (2014). Educational Statistics for Year 2013. Beijing: Ministry of Education Retrieved from http://old.moe.gov.cn/publicfiles/business/htmlfiles/moe/s8493/index.html (accessed 28/3/2017).

[21] MoE. (2015). $2015 \quad$ HEIs $\quad$ List). Beijing Retrieved http://www.moe.edu.cn/publicfiles/business/htmlfiles/moe/moe_634/201505/187754.html_(accessed 28/3/2017).

[22] Ou, Y. (2012). The Influence of Achievement Motivation and Attributional Beliefs on EFL Learning. (master), Xi'an International Studies University, Xi'an.

[23] Parkerson, J. A., \& et al. (1984). Exploring Causal Models of Educational Achievement. Journal of Educational Psychology, 76(4), 638-646.

[24] Pike, G. R., Kuh, G. D., McCormick, A. C., Ethington, C. A., \& Smart, J. C. (2011). If and When Money Matters: The Relationships among Educational Expenditures, Student Engagement and Students' Learning Outcomes. Research in Higher Education, 52(1), 81-106. doi:10.1007/s11162-010-9183-2.

[25] Reis, S. M., \& McCoach, D. B. (2000). The Underachievement of Gifted Students: What Do We Know and Where Do We Go? Gifted Child Quarterly, 44(3), 152-170. 
[26] Renninger, K. A., \& Hidi, S. (2011). Revisiting the Conceptualization, Measurement, and Generation of Interest. Educational Psychologist, 46(3), 168-184. doi:10.1080/00461520.2011.587723.

[27] Rimm, S. B. (1997). An underachievement epidemic. Educational Leadership, 54(7), 18-22.

[28] Stewart, E. (2008). School structural characteristics, student effort, peer associations, and parental involvement - The influence of school- and individual-level factors on academic achievement. In Educ. Urban Soc. (Vol. 40, pp. 179-204).

[29] VanAuker-Ergle, K. A. (2003). Barriers to low achievers' success in the elementary classroom as perceived by teachers: a qualitative study. (Ph.D), University of Florida,

[30] Whitmore, J. R. (1980). Giftedness, Conflict, and Underachievement. Boston: Allyn \& Bacon.

[31] Woolfolk, A. (2010). Educational psychology (11th ed.). Upper Saddle River, N.J.: Merrill.

Fei Ma was born in Xi'an China in 1977. He received his doctorate degree in education from University of Nottingham.

$\mathrm{He}$ is currently an associate professor in the School of Basic Science, Zhejiang Wanli University, Ningbo, China. His research interests include applied linguistics and EFL education. 